November - 2005

\title{
Problem-based Learning in an Online Course: A case study
}

\author{
James Cheaney and Thomas S. Ingebritsen \\ Iowa State University, USA
}

\begin{abstract}
Problem-based learning (PBL) is the use of a "real world" problem or situation as a context for learning. The present study explores the use of PBL in an online biotechnology course. In the PBL unit, student groups dealt with the ethical, legal, social, and human issues surrounding presymptomatic DNA testing for a genetic disease. Issues concerning implementation of PBL in the online environment are discussed, as are differences between online PBL and face-to-face PBL. This study provides evidence to suggest that PBL stimulates higher-order learning in students. However, student performance on a lower-level exam testing acquisition of factual knowledge was slightly lower for PBL students than for students who learned the same material through a traditional lecture-based approach. Possible reasons for this lower level of performance are explored. Student reactions and feedback to the PBL format yield more insight into issues surrounding the implementation of PBL in the online environment.
\end{abstract}

Keywords: problem-based learning; case-based learning; distance education; cooperative learning; genetic diseases; genetic testing, instructional design

\section{Introduction}

Problem-based learning (PBL), also known as case-based learning, is an increasingly integral part of education reform in the United States and around the world, especially in the medical and social sciences, and in pre-professional and professional programs (reviewed in Michel Bischoff, and Jakobs, 2002). While there is no universally-accepted definition of problem-based learning in the literature (Maudsley, 1999), the essence of PBL can be summarized as the use of a "real world" problem or situation as a context for learning (Morgan, 1983; Barrows, 1985; Boud, 1985; Duch, 1995; Domin, 1999; Michel et al., 2002). The purpose of PBL is to encourage student development of critical thinking skills, a high professional competency, problem-solving abilities, knowledge acquisition, the ability to work productively as a team member and make decisions in unfamiliar situations, and the acquisition of skills that support self-directed life-long learning, self-evaluation, and adaptation to change (Engel, 1991; Albanese and Mitchell, 1993; Ryan and Quinn, 1994). In PBL, this is achieved by using situations or problems presented in class that resemble reality. PBL is a student-centered constructivist approach to learning that facilitates the construction of a conceptual network of knowledge in students, which can then be applied in a wide range of practical settings (Creedy and Hand, 1994; Cruickshank and Olander, 2002). In many cases, the realistic problems used in PBL studies may not have a right or wrong answer. Instead, PBL works through five cognitive areas to stimulate learning: 
Problem-based Learning in an Online Course: A case study

Cheaney \& Ingebritsen

1. Activation of students' prior knowledge

2. Elaboration of prior knowledge through cooperative discussions

3. Restructuring of knowledge to fit the problem presented; construction of an appropriate semantic network through internal discourse

4. Learning in the scaffolding context of a real-world problem

5. Emergence of epistemic curiosity due to relevance of problem

(Schmidt, 1993)

In the PBL environment, students should be allowed to analyze the problem in its own and the student's context and environment (Coles, 1990, 1991) and to construct a method to arrive at a detailed analysis, if not a final conclusion (this process is sometimes referred to as "situationbased learning”) (Dockett and Tegel, 1993; Russell, Creedy, and Davis, 1994). Care must be taken to ensure that students are not forced to follow one particular path to a predetermined conclusion (sometimes referred to as "solution-based learning" (Cowdroy, 1994); however, for an opposing viewpoint on the importance of actually solving the problem, see de Shazer, 1985). In PBL, the focus is on the process, not the product (Patel, Groen, and Norman 1991; Margetson, 1994; Shannon and Brine, 1994).

PBL is extremely consistent with constructivist philosophy. Constructivism (of which there are many different flavors) is, in the general sense, a Kantian philosophy (also heavily influenced by Descartes) which views knowledge as something the learner must uniquely construct for and by himself or herself in order to have a personal understanding of their own interaction with their environment (Kant, 1800/ 1974; Dewey, 1929; von Glaserfeld and Smock, 1974; Hilgard and Bower, 1975; Ryle, 1975; Blais, 1988; von Glaserfeld, 1989; Schmidt, 1993). Savery and Duffy (1995) identify three fundamental constructivist principles: understanding comes from our interactions with the environment (but not in the behaviorist stimulus-response fashion); cognitive conflict stimulates learning (expanded upon by Willingham, 2004); and knowledge evolves through social discourse and evaluation of the viability of individual understandings. All these principles are explicitly fulfilled through PBL. PBL instructors, as a result, become facilitators, coaches, and mentors, rather than the positivist stereotypical "fount of knowledge" (Collins, Brown, and Newman, 1989; Mullins, 1994; Russell et al., 1994; Mierson, 1998). PBL is pedagogically suited to many different types of constructivism, including Piagetian cognitive constructivism (Kanuka and Anderson, 1999), radical constructivism (in which PBL can be incorporated with cognitive apprenticeship) (Collins et al., 1989; Duffy and Bednar, 1991; Honebein, Duffy, and Fishman, 1993), situated constructivism (crisscrossing landscapes) (Spiro and Jehng, 1990; Molenda, 1991; Spiro, Feltovich, Jacobsen, and Coulson, 1991), and coconstructivism (in which PBL can be incorporated with reciprocal teaching) (Shunk, 2000).

PBL is typically conducted using cooperative learning groups (Anderson and Henley, 1994; White, 1996). Ideally, cooperative student learning groups should be as heterogeneous as possible to maximize the breadth of experiences and academic skills available to the group (Cuseo, 1996). Nevertheless, the PBL paradigm can provide sufficient scope for individual study disciplines to be developed (Navarra, Levin, and Navarra, 1993; however, the opposite viewpoint is implied by Tolnai, 1991). 
PBL is usually conducted in a face-to-face setting. Less is known about the use of PBL in the electronic-based distance-education "virtual classroom," due to the relative novelty of electronicbased distance education. Klemm (2002) found that cooperative learning case study groups thrive in the electronic environment; however, Klemm's “case studies” were actually reviews of journal articles, and computer conferencing was used as an adjunct to face-to-face meetings between students in a traditional class. The Internet, however, allows a different kind of class experience that does not require students to ever meet each other in person. The versatility of the Internet, combined with its cost-effectiveness in overcoming the geographic limitations of the traditional university, presents educators with an unrealized potential to produce pedagogically- and scientifically-sound authentic learning experiences, including PBL, that allow for multidisciplinary projects, cooperative learning groups, flexible scheduling, and authentic assessments in distance education courses. They may revolutionize, supplement, complement, and enrich science education, both at a distance and in the traditional college setting.

\section{Design of the Problem-based Learning Unit and Assessment}

A PBL unit has been used in several versions in an online undergraduate/ graduate course entitled "Biotechnology in Agriculture, Food and Human Health." This is a three-credit survey course that covers technology and applications of biotechnology as well as ethical, legal, and social issues (ELSI) associated with its use. When first conceived, the principal student market for the class was considered to be educators. Since then, however, the bulk of the students have been a mix of traditional undergraduate and graduate students majoring in molecular biology or genetics or working in an campus-based lab, professionals working for seed or other biotechnology companies (often these students have a business rather than a science background), and farmers who want to learn more about the seeds they are planting and harvesting. There have been other students from all walks of life, including military personnel, lawyers, engineers, and an assistant state secretary of agriculture. Students are geographically diverse, with nearly every U.S. state represented, as well as students logging in from Canada, Germany, and Kenya. The course is offered three times per year, and the number of students typically ranges from 15-30 students per semester, with a typical 25-30 percent drop rate between the beginning and end of the semester.

The course consists of online audiovisual lectures that are modeled after lectures in a face-to-face classroom (utilizing online slides accompanied by a streaming audio/ visual lecture), authentic learning assignments, and reading assignments in a required textbook and from various online resources. Approximately 60 percent of the grade in the course is based on authentic learning activities and the other 40 percent is from online exams based on content in the online lectures and reading material. Exams are password-protected and require the presence of an approved proctor (such as a county extension agent) to prevent student cheating. Within the class architecture, students can communicate with the instructor and with each other through an inclass email system, a bulletin-board-style discussion forum, and both private and public chat rooms.

We decided to use PBL pedagogy for a five-week unit about genetic testing technologies. One of the most interesting aspects of biotechnology are the ethical, legal, and social issues (ELSI) raised by these technologies. In the case of the genetic testing unit, one intriguing ELSI question is whether genetic testing is beneficial in a situation where there is no cure for the genetic disease. The PBL approach allowed us the use this interesting ELSI question to capture student interest and to motivate learning about the more technical aspects of the topic (nature of genetic diseases and genetic testing technologies). 
In the PBL unit, students are asked to think about a fictional 33-year-old man named Robert. Robert's mother died of an incurable fatal neurological genetic disease called Huntington disease (HD). Huntington disease is caused by a defect in a gene (HD, on chromosome 4) coding for a protein called 'huntingtin.' This defect is inherited in a dominant fashion (which means that inheritance of just one form of the abnormal gene usually leads to the development of HD). Thus, assuming there is no history in his father's side of the family, Robert has a 50 percent chance of having inherited the abnormal form of HD. Symptoms are classically manifested as progressive involuntary spasms and dementia. The age of onset is variable, but usually occurs between the ages of 15 and 60, depending on the severity of the defect. A review of more technical information about HD can be obtained from the National Center for Biotechnology Information's Internet site (http://www.ncbi.nlm.nih.gov/entrez/dispomim.cgi?id=143100).

Robert's mother began exhibiting HD symptoms at the age of 34, and survived for 16 years before succumbing at 50. Despite the lack of a treatment or cure for HD, there is a presymptomatic DNA test to determine the nature of a patient's HD gene. A positive result usually means the patient can look forward to an early and unpleasant death, and currently there is nothing he or she can do about it.

The ultimate student objective of the class activity is to make a decision about whether Robert should undergo pre-symptomatic DNA testing for HD. Student groups role-play various stakeholders in Robert's decision (such as Robert himself, his wife, his 4-year-old daughter, his employer, and his insurance company) and decide over the course of the unit through meetings, assignments, and research, whether to advise the man to take the test or not. The learning objectives for the PBL problem are as follows:

- Understand the nature and mode of inheritance of genetic diseases

- Gain an appreciation of the human cost of genetic diseases

- Understand the principles and technologies used in genetic testing

- Gain an appreciation of ethical, legal, and social issues associated with genetic testing

- Develop problem-solving skills

- Learn how to find and process information in Web-based databases

Assessment of authentic learning experiences is a controversial part of the literature surrounding PBL. It is difficult to devise a strictly objective means of assessing student performance in learning material. Assessments of authentic learning experiences must involve problems and provide opportunities where the complexity of the student's thinking process is exhibited (Wright, Millar, Kosciuk, Penberthy, Williams, et al., 1998). In the PBL unit that we are utilizing, assessment will be made through student performance on traditional exams consisting of a mix of multiple-choice and essay questions, the students' presentation of different aspects of the problem through the process of writing papers, and their ability to internalize their understanding of biotechnology methods and ELSI in order to devise a novel genetic test or a new means for Robert to approach his problem and decision.

The cooperative learning groups for this unit were assigned into groups ranging from 2-3 in some semesters to 3-4 in some semesters, based on the number of students enrolled in the class. Groups 
were assigned as to provide a mix of students taking the class for undergraduate or graduate credit. Groups were also assigned to provide a geographic mix, to prevent some groups from having an unfair advantage if they decided to meet in person (if all members lived, for example, in the same county), while other groups were limited to chat rooms, email, discussion forums, and other teleconferencing means. Geographic diversity in each group ensures that all groups must use the electronic means provided in the class architecture to hold meetings (though there was no attempt to prevent students from using external means of contacting their peers, such as standard email or instant messaging). No attempt was made to separate students by innate ability, as reflected by GPA or overall grade in the class.

Two versions of the PBL unit were tested. In the preliminary version of the PBL unit (which was used for only two semesters) there were three assignments (Defining the Issues, Gathering Information, and Solving the Problem), which served as guiding problems for the unit. In addition, both a pre-unit exam and a post-unit exam were utilized.

In the "Defining the Issues" assignment, student groups were asked to identify the issues involved in Robert's decision and the types of information that will be needed for Robert to make an informed decision. Each group posted a summary of the ideas developed on the course discussion forum. Students were encouraged not to conduct research on HD (yet), or to reach a decision (yet) on whether Robert should have the genetic test done. According to the learning taxonomy developed by Bloom, Engelhart, Furst, Hill, and Krathwohl (1956), students were engaged in analysis of Robert's situation and applying their own previous knowledge and values to some of the concerns he will be facing.

In the "Gathering Information" assignment, student groups were required to write a short research paper about HD. The paper included information about clinical features of the disease, information about the gene, the genetic defect and the mode of inheritance of the disease, and information about genetic testing for Huntington's disease. Resources for the paper included online lectures and textbook reading assignments about genetic diseases and genetic testing technologies as well as Internet resources (e.g., molecular biology and genetics databases, informational websites). This assignment engaged students in comprehension of their research concerning HD and their ability to synthesize that research into a comprehensive whole.

In the "Solving the Problem" assignment, student groups used a structured decision-making process to decide whether the individual should be tested for the genetic disease. The decisionmaking process involved identifying the stakeholders, brainstorming about possible options, considering the effect of various options on all of the stakeholders, and finally choosing the "best" solution. Students then wrote a report on this decision, focusing on the logical defense and reasoning for their opinion. Students were not graded on their opinions per se, but on the persuasiveness and completeness of their arguments. Students applied their knowledge to the final situation and synthesized an appropriate response considering the varied and diverse concerns of the various stakeholders. In justifying their final recommendation, students evaluated the various arguments for and against Robert having the test done and all the variations thereof (such as when Robert should have it done, who should be involved in the decision, and so forth), and argued in defense of their decisions. These arguments reflected their own construction of values based on their research, while recognizing those arguments' inherent subjectivity. According to Bloom and colleagues (1956), therefore, the "Solving the Problem" assignment can be classified under the application, synthesis, and evaluation domains. 
Exam questions were taken from a test bank with several possibilities for each question. One possibility for each question was picked randomly by the examination software for the pre-unit exam and again for the post-unit exam. This ensured that questions were similar in difficulty for the pre-unit exam and the post-unit exam, and yet minimized the likelihood of students seeing the same question more than once. Exam questions tested understanding of inheritance patterns of genetic diseases and specific DNA technology techniques used in diagnosis of genetic diseases.

A problem with the preliminary version of the PBL unit was the narrow focus on just one genetic disease (HD). Because of this the unit was revised by replacing the "Gathering Information" assignment with two other assignments, "Genetic Diseases" and "Genetic Testing", which gave the students a broader view of genetic diseases and DNA-based diagnoses. The other two assignments, "Defining the Issues" and "Solving the Problem," were used unchanged in the final version of the PBL unit. To date, this PBL unit has been used for 13 semesters.

In the "Genetic Diseases" assignment, students chose a genetic disease from a list of genetic diseases available at a National Institutes of Health (NIH) website. They were required to do research on the Internet in order to answer a set of specific questions about the disease and the characteristics of its manifestation, and the gene and genetic mutation associated with this genetic disease. The assignment was conducted as an individual student assignment. This assignment tests student comprehension of information gained from their research. This assignment also provides students with a background in other genetic diseases that can sometimes be manifested in added evaluation abilities when, in the "Solving the Problem" assignment, some students compare and contrast HD with the disease they picked for this assignment.

In the "Genetic Testing" assignment, the students are asked to design a novel pre-symptomatic genetic test for a fictional genetic disease, based on their understanding of DNA technologies used for genetic diagnoses. Resources for the two assignments included online lectures about genetic diseases and genetic testing technologies, textbook reading assignments and Internet resources. Unlike "Genetic Diseases," "Genetic Testing” was a group assignment testing their ability to synthesize a test using real technology for a fictional genetic defect.

The PBL unit was worth 28 percent of the final grade in the course. Student assessment was based on written assignments (2/3 of grade) and a post-unit exam (1/3 of grade). The pre-unit exam was discontinued for the final version of the PBL unit. The test bank for post-unit exam questions was unchanged from that used in the earlier version. There was an added question in the post-unit exam about the legality of an action by Robert's employer or insurance company predicated on his testing positive for HD. This question required students to research the legal basis for their answer online (so this question is referred to as the "open book" section, even though there is no physical book involved in the students' research for this particular question). Table 1 summarizes the main characteristics of the two versions of the PBL unit. 
Problem-based Learning in an Online Course: A case study

Cheaney \& Ingebritsen

Table 1. Summary of characteristics of two versions of PBL unit used in biotechnology course

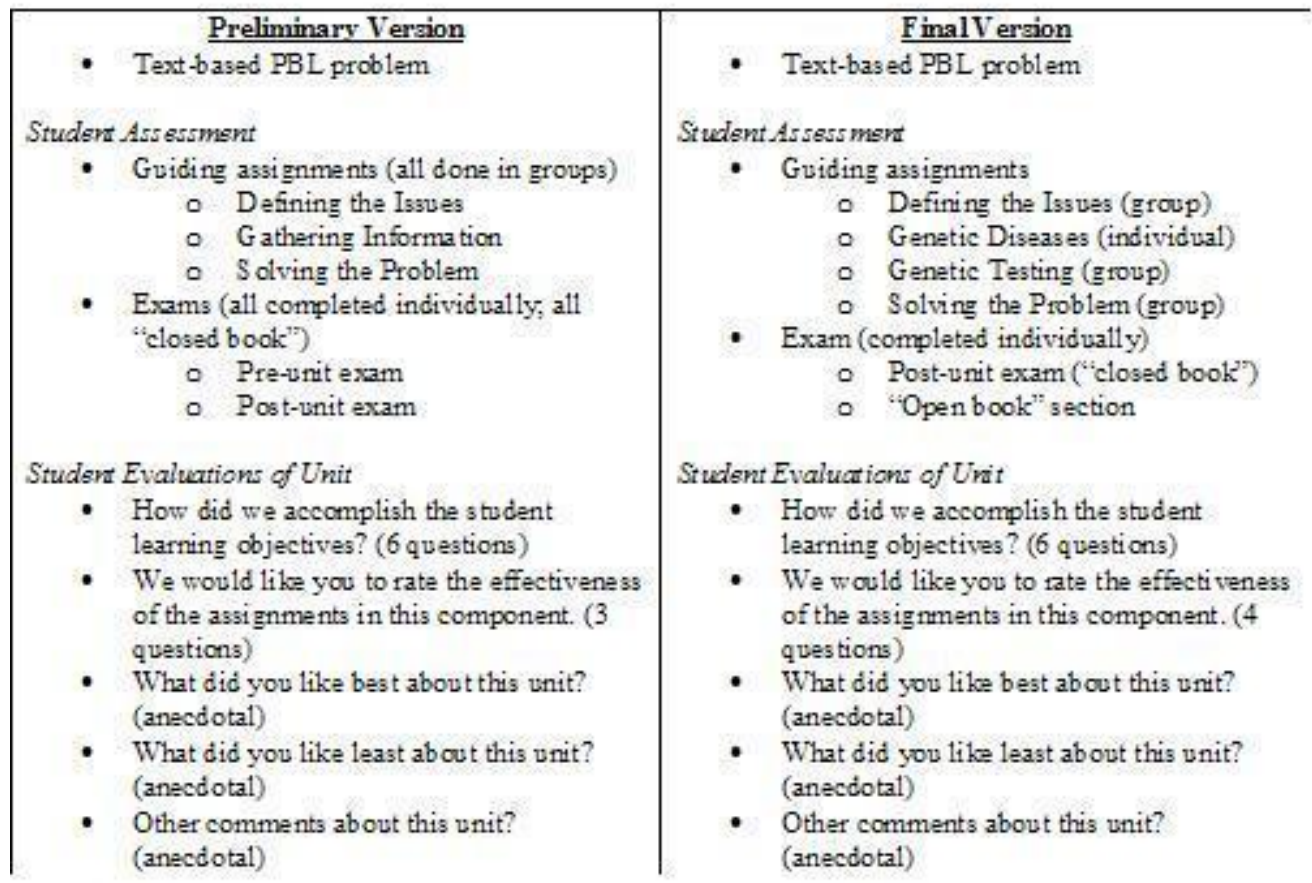

\section{Evaluation}

The preliminary version of the PBL unit utilized a pre-unit exam to test student knowledge and understanding of genetic diseases and genetic diagnosis technology before beginning the PBL unit. Students who completed the exam received extra credit points, equivalent to just under 0.3 percent of the total points possible for the entire course. When pre-unit exam scores are compared to the scores for the exam administered after the PBL unit (which was a required exam equivalent to 12 percent of the total points possible for the entire course), a measure of the increase of student factual knowledge can be determined. This comparison was conducted using Student's t test (Steel and Torrie, 1960). The average scores on the pre-unit exam $(47.0 \% \pm 19.2 ; n=20)$ and the post-unit exam $(79.7 \% \pm 18.2 ; n=20)$ were significantly different $(P=3 \times 10-6)$, indicating a significant increase in factual knowledge.

Students who completed the final version of the PBL unit had lower exam scores than those who had completed a unit covering the same material using a lecture-based instructor-centered approach, based on a very similar multiple-choice-and-essay post-unit exam $(P=0.016$; see Table 2 for results). The lower exam scores for the PBL students represented a difference of one half of a letter grade for the exam. It is possible that the students that completed the lecture-based approach were more proficient overall due to previous exposure to biotechnology theory and laboratory work, so overall grades for the entire course were compared between these two groups. No significant differences in overall grades were found $(P=0.620$; see Table 2$)$. 
Problem-based Learning in an Online Course: A case study

Cheaney \& Ingebritsen

Table 2. Scores for post-unit exam, overall grade for course, and assignments used in PBL format for genetic diagnosis unit compared to scores using lecture-based format for genetic diagnosis unit.

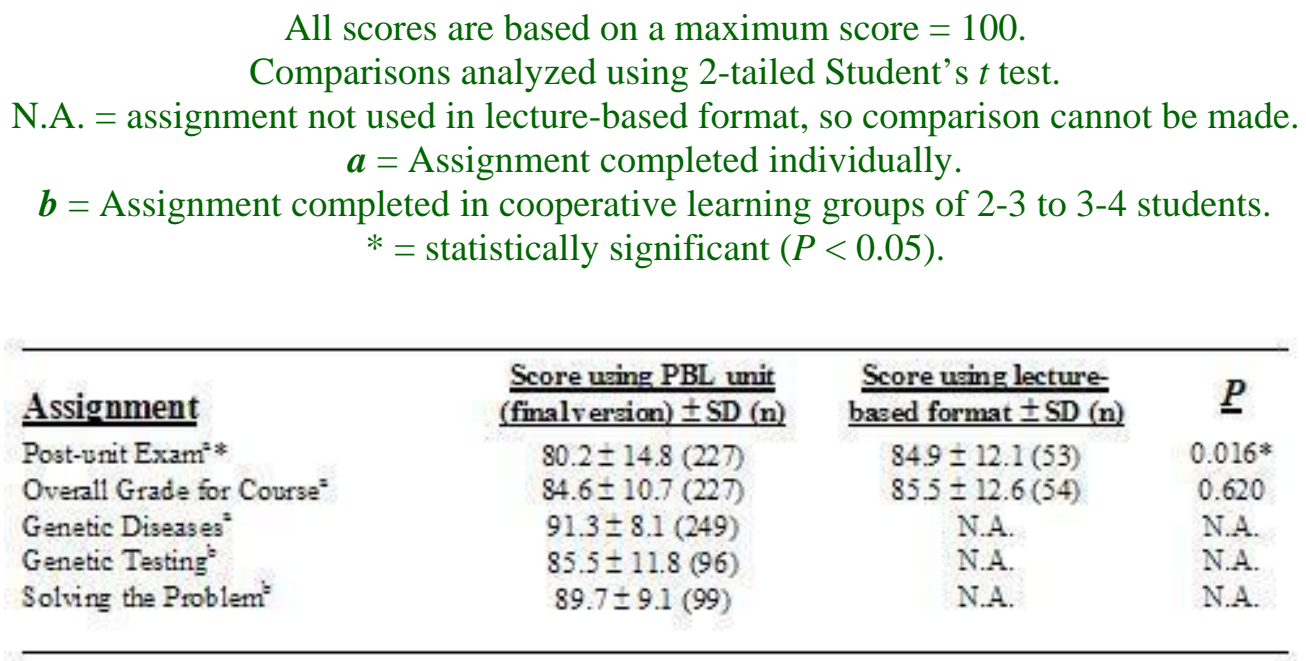

Assignment scores are summarized in Table 2. The lower n values for the "Genetic Testing" and "Solving the Problem" assignments represent each cooperative learning group being treated as an experimental unit (the "Genetic Diseases" assignment and the exams were completed individually). Based on the grading criteria discussed previously, it is reasonable to assume that, despite their subjective nature, the learning objectives of the unit were fulfilled, with excellent consideration demonstrated by student groups in general in consideration of Robert's options and the impact each has on their stakeholder. Assignment scores for "Defining the Issues" were not statistically analyzed due to different grading criteria being adopted for this assignment as the study progressed.

In any learning situation, student attitudes greatly influence the degree to which learning can occur (Henderleiter and Pringle, 1999). Student attitudes were determined using their responses to questions posed on the end-of-semester student evaluations concerning the PBL unit. These questions are listed in Table 1. Results for the questions asking about the learning objectives and the assignments themselves are summarized in Table 3. In anecdotal comments about what students liked most and least about the PBL unit, students indicated that they appreciated the independent research (when the division of labor with their groupmates was successful), exploring the World Wide Web, learning about Huntington disease and other genetic diseases, and communicating with other students about the problem. The cooperative learning aspect of the PBL offered students experience in time management, schedule coordination, and division of labor. Some students, however, expressed concerns about scheduling difficulties for synchronous electronic meetings with their cooperative groups, and the technical difficulties inherent in an online setting (such as Internet lag, computer crashes, or bandwidth or browser problems). In addition, group activities decrease some of the temporal and geographic flexibility advantages that asynchronous online courses offer. 
Problem-based Learning in an Online Course: A case study

Cheaney \& Ingebritsen

Table 3. Student evaluation ratings in response to the problem-based learning unit in an online biotechnology class. Ratings are based on a scale of 1 (excellent) to 5 (poor)

\begin{tabular}{|c|c|c|c|}
\hline & & $\begin{array}{c}\text { Rating Average } \\
\pm \mathrm{SE} \\
\end{array}$ & $\mathbf{n}$ \\
\hline \multicolumn{4}{|c|}{ How w ell did we accomplish the following learning objectiv es: } \\
\hline 1. & Understand the nature and mode of inheritance of genetic diseases & $1.77 \pm 0.70$ & 166 \\
\hline 2. & Gain an appreciation of the hmman cost of genetic diseases & $1.63 \pm 0.67$ & 166 \\
\hline $\begin{array}{l}3 . \\
4 .\end{array}$ & $\begin{array}{l}\text { Understand the principles and technologies used in genetic testing } \\
\text { Gain an appreciation of ethical, legal, and social issues as sociated }\end{array}$ & $1.75 \pm 0.73$ & 165 \\
\hline & with genetic testing & $1.75 \pm 0.80$ & 166 \\
\hline 5. & Develop problem solving skills & $2.17 \pm 0.88$ & 166 \\
\hline 6. & Learn how to find and process information in Web-based databases & $1.95 \pm 0.96$ & 38 \\
\hline \multicolumn{4}{|c|}{ We would like you to rate the effectiveness of the assignments in this comp onent. } \\
\hline 7. & Defining the issves & $2.15 \pm 0.91$ & 166 \\
\hline 8. & Genetic Diseases & $1.86 \pm 0.75$ & 166 \\
\hline 9. & Genetic Testing & $2.02 \pm 0.82$ & 166 \\
\hline & Solving the problem & $2.24 \pm 0.93$ & 164 \\
\hline
\end{tabular}

\section{Discussion}

A major difference between PBL in a traditional face-to-face learning environment and in an online learning environment is the way in which group members interact with each other. In traditional PBL groups typically meet face-to-face in or outside of class time. In the online environment all meetings take place electronically. These meetings may occur synchronously using the telephone, text-based chat or audio/ video conferencing or asynchronously using discussion forums or email. There are strengths and weaknesses to each of these approaches.

Synchronous communication technology provides for spontaneity and give-and-take between group members with immediate feedback. A problem with this approach is the difficulty of scheduling synchronous meetings. This is especially true for non-traditional students. Another problem with synchronous communication is the clunkiness of text-based chat. Problems here include typing abilities (especially speed) and the ability to decipher multiple simultaneous threads of conversation. Audio- or videoconferencing is a superior approach for synchronous communication, but it is not applicable in our situation because we have chosen to restrict the course to low bandwidth technologies (i.e., phone/ modem) in order to make the course as widely accessible as possible.

Asynchronous interaction provides more time for the individual research required for to a student to fulfill his or her role in the group, and also stimulates reflection on the relevant issues the group is discussing. Asynchronous interaction, however, often inhibits spontaneous development of ideas. A student may also make significant progress down the "wrong path" through research before his or her teammates can correct an improper understanding of that student's role in the group for that particular assignment. In addition, asynchronous interaction inhibits the quick allocation of tasks and formation of schedules to get problem-solving activities completed (Garrison and Anderson, 2003). 
When the PBL unit was first included in this course, student interaction was generally evenly balanced between asynchronous communication (discussion forums) and synchronous communication (chat room, telephone). As the semesters passed, the use of the chat rooms within the course architecture decreased steadily, while the use of the asynchronous discussion forums increased steadily. This was due in part because we promoted the use of asynchronous technologies by establishing private discussion areas for each group and by encouraging them to meet asynchronously in our initial instructions. We did this so that we could more effectively monitor group interactions. Additionally we have noted anecdotally that, while the proportion of non-traditional to traditional students has remained relatively constant, it now seems that nearly all of our traditional students are working their way through college, as well as non-traditional students. It is thus much harder to schedule synchronous meeting times that agree with the schedules of everybody in the cooperative group. With the widespread advent of email in the late 1990s and early 2000s, students are also much more comfortable with asynchronous communication.

Another difference between distance PBL and face-to-face PBL is the role of the instructor. In PBL the instructor serves as a facilitator who gives feedback, challenges students' understanding of concepts without dominating the group, monitors group dynamics, manages conflicts, knows when and when not to intervene, and empowers students (Mierson, 1998). The role of the instructor as facilitator is more difficult and time-consuming in a distance-education PBL setting than in a face-to-face PBL setting, because the instructor must rely on student self-reporting to identify dysfunctional groups (especially if the group is communicating mostly by private means such as email or chat rooms), or must monitor the group's discussion forum. Sometimes students must be prodded by the instructor to report on their own group dynamics. In our study, several assignments, such as "Defining the Issues," had a small point value given to discussions about their own group dynamics, whether students were equally sharing the division of labor and writing duties with their peers, and so forth.

Another consideration that is especially important in distance education is that of student motivation. Wankat and Oreovicz (1991) identify two forms of motivation, intrinsic (internal pleasure from the intellectual challenge of learning, social interaction, and so forth), and external (grading, encouragement from the instructor, etc.).

An online distance education requires a great deal more intrinsic motivation than a traditional face-to-face course. Rather than having a set-aside time for students to focus exclusively on their learning by going to class, the learning experience is brought to the student's home where it must compete against family obligations, social interruptions, housework, and entertainment. Many students report motivation as a prime difficulty in their evaluations at the end of the semester. The main extrinsic motivation (grading) leads to procrastination followed by cramming, but in distance-education PBL, where students must schedule working on the problem around the schedules of their groupmates, procrastination is not possible without leading to an unequal division of labor - and, indeed, procrastination by one member of a group often turns out to be the root cause of many dysfunctional groups. Assignments (extrinsic motivation) must be made due at periodic intervals (we have assignments due at one-week intervals through the five-week PBL unit) to maintain that extrinsic motivation, which helps support students' intrinsic motivations, and to help prevent procrastination.

A major goal of the PBL unit was to promote higher-order learning - application, analysis, synthesis, and evaluation in the taxonomy of Bloom et al. (1956). Assignments for the PBL unit 
were designed to evaluate higher-order learning of the human cost and ELSI of genetic diseases and genetic testing. Despite the necessarily subjective nature of the grading process, the reports by the student groups indicate a high level of comprehension of research ("Genetic Diseases"), analysis of relevant issues ("Defining the Issues"), synthesis of ideas in response to a novel situation ("Genetic Testing”), and application and evaluation of resulting principles to the central core question ("Solving the Problem") within the group. Students integrated their learning of material from this course with their individual background and experiences, fusing their ideas to a common consensus within the student groups. This is consistent with Wright and colleagues (1998), who found when dealing with student-centered cooperative active learning that differences in perceived student competence and "student maturity" are correlated with the authentic development of higher-level thinking skills. Another study found that medical students who completed PBL-intensive medical training scored significantly higher than their colleagues who had experienced a mostly-lectured-based curriculum in five areas relating to humanism and social learning, were much more likely to have pursued careers in primary care or psychiatry (as opposed to, for example, surgery or research), and were more likely to believe that their training continued to influence their thinking (Peters, Greenberger-Rosovsky, Crowder, Block, and Moore 2000). This indicates a greater understanding of the ELSI and human issues through PBL.

What is the impact of PBL on lower-level learning (knowledge and comprehension of factual information)? Does the process of knowledge construction inherent in PBL compromise the acquisition of factual knowledge that is central to science? We addressed this question using exams which measured students' knowledge and comprehension of the basic factual information about genetic diseases and genetic testing. Comparison of pre-module and post-module exam scores indicates that significant factual knowledge is acquired through the PBL format, just as it is in a lecture-based format. The post-exam scores for the PBL format, however, were a half grade lower than the post-exam scores when the material was taught using conventional pedagogy. This effect was specific for the PBL unit and was not seen when comparing overall course grade. This suggests that low-level learning may be somewhat compromised using the PBL approach. A note of caution here is that the pre-PBL sample size was relatively small $(n=$ 53) and may not be representative.

Why might students score lower on exams testing low-level knowledge and comprehension with the PBL format? Wankat and Oreovicz (1991) propose that learning takes place when a student is presented with information in such a way as to cause disequilibrium. Failure to achieve this disequilibrium may cause a student to feel complacent, and there is no motivation to learn. A student in a state of disequilibrium feels a need to ease his or her intellectual discomfort, and is thus motivated to do something. In other words, in order to learn, students must first understand what they don't know (Bransford and Schwartz, 1998). In the process of learning, a student construct an intellectual scaffolding with supporting concepts that allows him or her to return to equilibrium.

In this study, the students generated their own disequilibrium by completing the "Defining the Issues" assignment, where they acknowledged the information Robert would need to accumulate in order to make an informed decision. Not only would they need to learn much more about the human issues and ELSI surrounding Robert's dilemma, but they would also need to learn much more about the characteristics of genetic diseases and the techniques used in genetic testing. The instructor is responsible for facilitating student access to the information available that will allow the student to begin to construct an intellectual framework; however, the instructor should be careful not to provide too little support (which makes the student feel lost) or too much support (which gives the student no reason to actively participate in his or her own learning) (Erlendsson, 
2001). This is more difficult in an online class where an instructor does not have face-to-face contact with students, and more difficult in a PBL setting where students are searching to develop their answers largely on their own. Intimidation by the immensity and complexity of the electronic Internet may also be a factor (Jensen Guttschow, and Hill, 2002). It is possible in our case that the PBL format may be so alien to students who are veterans of a more traditional format, that they struggle in an environment where they, rather than their instructor, directs their learning (Cruickshank and Olander, 2002). PBL requires much more motivation on the student's part, as well as more work outside of class (Herreid, 2000). Time constraints may play another factor. While completing the unit, students are focused on the immediate goal of completing the assignments, which are geared to higher-order learning. If the development of higher-order understanding by the students is a goal however, then assessment should be in the form of problems and opportunities that demonstrate the complexity of the student's thinking process (Wright et al., 1998). Performance on a traditional multiple-choice exam reflects only low-level command of the subject matter, not the high-level understanding that is the focus of PBL. The literature, however, indicates no differences in gains of student understanding of factual material through PBL compared to a traditional lecture-based and instructor-centered setting (Dyke, Jamrozik, and Plant, 2001).

In evaluations of this unit, students appreciated many of the advantages of working together with their teammates to develop answers to the problems presented, such as "being able to bounce ideas off" their teammates. PBL also has the advantage of reducing the sense of isolation, which reduces motivation that pervades much of distance education. Students did take special notice of inherent cooperative learning disadvantages, such as problems in coordinating schedules that are also present in real-world teamwork. There are also disadvantages common to all online ventures (i.e., technical problems such as Internet lag, computer crashes, and other software or hardware problems), and disadvantages unique to PBL and/ or cooperative learning in an online setting (i.e., decreases in temporal and geographic flexibility; differences in feedback, compromise ability, and timeliness between students within a group). These difficulties have been noted by other researchers, who suggest that improvements in the support network (i.e., computer software) might help students better manage the division of labor, scheduling, and management of documents chronicling the development of their thoughts (Garrison and Anderson, 2003).

\section{Conclusion}

PBL has been effectively used to promote higher order learning in many disciplines in a face-toface environment. We wanted to know whether this pedagogy would also be effective in an online environment. Our results indicate that higher-order learning and construction of understanding of the science and ELSI of genetic testing is taking place through the use of this PBL environment. Student reaction to the course was generally positive, but with some reservations about the effectiveness of group work in an online class.

Is virtual PBL a viable pedagogy in other online courses? There is a substantial body of research showing that there is no significant difference in learning between the Internet-based and face-toface educational environments (reviewed in Russell, 2001). Is the use of PBL in the online environment any different? There are obvious differences between face-to-face PBL and online PBL with regards to cooperative communication (asynchronous vs. synchronous), scheduling, interpersonal relationships, student motivation, timeliness, and technical problems with hardware, software, or infrastructure. We feel, however, with student performance on this unit that the advantages of the cooperative PBL format, such as increased higher-order learning and deeper 
student understanding, balance the disadvantages experienced by certain students and student groups. It is our belief that PBL is a valid and valuable means of increasing student learning in any online class where higher-order learning is desirable.

We found that there was a small, but statistically significant, difference in lower level learning as measured by an exam at the end of the unit. It is not clear whether this is an inherent feature of PBL in an online environment or whether it is simply a feature of this particular case. There is extensive literature showing that there is no significant difference between lecture-based student performance and PBL student performance on standardized exams (Wright et al., 1998; Dyke et al., 2001; Cruickshank and Olander, 2002; Michel et al., 2002). However, standardized exams are specifically designed to test knowledge of the type that is easily conveyed through a lecture-based format. Wright et al. (1998) and Michel et al. (2002) suggest that the strength of PBL is not measured by student performance on multiple-choice exams, but by demonstration of higherorder learning through guided authentic learning activities.

A factor that may influence student learning is the sense of connection - or lack thereof - to the central problem that the students face. The PBL unit in this study is text-based, but could be recontextualized to be more integrated, thus transforming the online delivery of this PBL unit from being oriented towards a technical imperative to being oriented towards a pedagogical imperative (Oliver and Harrington, 2000). In other words, the PBL unit could be made more immersive for students by using seamless access to resource material such as streaming multimedia that takes them intimately into Robert's world. Immersion transforms the PBL situations, such as Robert's dilemma, from an abstraction into a context "within which a particular situation is perceived, interpreted, and judged" (Broudy, 1976). Work is in progress to explore the effects of adopting an immersive multimedia-rich environment on fulfillment of the learning objectives of this PBL unit.

\section{Acknowledgements}

The authors wish to thank M. Duane Enger for his helpful comments on the manuscript. This work was supported in part by a grant from the Computer Advisory Committee of the Iowa State University College of Liberal Arts and Sciences.

\section{References}

Albanese, M. A., and Mitchell, S. (1993). Problem-based Learning: A review of literature on its outcomes and implementation issues. Academic Medicine 68, 52 - 81.

Anderson, P., and Henley, I. (1994). Problem-based learning and the development of team skills in aviation studies. In S. E. Chen, R. Cowdroy, A. Kingsland, and M. Ostwald (Eds.), Reflections on Problem Based Learning (p. 319-345). Sydney: Australian Problem Based Learning Network.

Barrows, H. (1985). How to Design a Problem-Based Learning Curriculum for the Preclinical Years. New York: Springer.

Blais, D. M., (1988). Constructivism: A theoretical evolution in teaching. Journal of Developmental Education, 11(3) 2 - 7. 
Problem-based Learning in an Online Course: A case study

Cheaney \& Ingebritsen

Bloom, B. S., Engelhart, M. D., Furst, F. J., Hill, W. H., and Krathwohl, D. R. (1956). Taxonomy of Educational Objectives: Part I, Cognitive Domain. New York: McKay.

Boud, D. J. (1985). Problem-based learning in perspective. In Problem-Based Learning in Education for the Professions. Sydney: Higher Education Research and Development Society of Australasia.

Bransford, J. D., and Schwartz, D. L. (1998). Rethinking transfer: A simple proposal with multiple implications. Review of Research in Education 2(4), 61 - 100.

Broudy, H. S. (1976). Types of knowledge and purposes of education. In R. C. Anderson, R. J. Spiro, and W. E. Montague (Eds.) Schooling and the Acquisition of Knowledge (p. 1-17). Hillsdale, NJ.: Lawrence Erlbaum Associates.

Coles, C. R. (1990). Evaluating the Effects Curricula Have on Student Learning: Toward a more competent theory for medical education. In Z. M. Nooman, H. G. Schmidt, and E. S. Ezzat (Eds.) Innovation in Medical Education: An Evaluation of Its Present Status (p. 7687). New York: Springer.

Coles, C. R. (1991). Is problem-based learning the only way? In D. Boud and G. Feletti (Eds.) The Challenge of Problem-Based Learning (p. 295-307). London: Kogan Page.

Collins, A., Brown, J. S., and Newman, S. E. (1989). Cognitive Apprenticeship: Teaching the crafts of reading, writing and mathematics. In L. B. Resnick (Ed.) Knowing, Learning, and Instruction: Essays in Honor of Robert Glaser (p. 453-494). Hillsdale, NJ: Lawrence Erlbaum Associates.

Cowdroy, R. M. (1994). Concepts, Constructs and Insights: The essence of problem-based learning. In S. E. Chen, R. Cowdroy, A. Kingsland, and M. Ostwald (Eds.) Reflections on Problem Based Learning (p. 45-56). Sydney: Australian Problem Based Learning Network.

Creedy, D., and Hand, B. (1994). Determining changing pedagogy in PBL. In S. E. Chen, R. Cowdroy, A. Kingsland, and M. Ostwald (Eds.) Reflections on Problem Based Learning (p. 141-156). Sydney: Australian Problem Based Learning Network.

Cruickshank, B. J., and Olander, J. (2002). Can problem-based instruction stimulate higher order thinking? Journal of College Science Teaching 31(6) 374 - 377.

Cuseo, J. B. (1996). Cooperative Learning: A Pedagogy for Addressing Contemporary Challenges and Critical Issues in Higher Education. Stillwater, OK.: New Forums Press and the Professional and Organizational Network in Higher Education.

de Shazer, S. (1985). Keys to Solution in Brief Therapy. New York: Norton.

Dewey, J. (1929). The Quest for Certainty. New York: Minton. 
Dockett, S., and Tegel, K. (1993). "But we was just turtles:” Situation-based learning in early childhood teacher training. Australian Journal of Early Childhood 18(3) 43 - 48.

Domin, D. (1999). A review of laboratory instruction styles. Journal of Chemical Education 76(4) $543-547$.

Duch, B. J. (1995). What is problem-based learning? About Teaching: A newsletter of the Center for Teaching Effectiveness, 47. Retrieved October 7, 2005 from: http://www.udel.edu/pbl/cte/jan95-what.html

Duffy, T. M., and Bednar, A. K. (1991). Attempting to come to grips with alternative perspectives. Educational Technology 31(10) 12 - 15.

Dyke, P., Jamrozik, K., and Plant, A. J. (2001). A randomized trial of a problem-based learning approach for teaching epidemiology. Academic Medicine 76(4) 373 - 379.

Engel, J. (1991). Not just a method but a way of learning. In D. Boud and G. Feletti (Eds.) The Challenge of Problem-Based Learning (p. 21-31). London: Kogan Page.

Erlendsson, J. (1991). Student Motivation. Retrieved June 30, 2005 from: http://www.hi.is/ joner/eaps/wh_motia.htm

Garrison, D. R., and Anderson, T. (2003). E-Learning in the 21st Century: A framework for research and practice. London, UK.: RoutledgeFalmer.

Herreid, C. F. (2000). I never knew Joe Paterno. Journal of College Science Teaching 29(4), 158 $-161$.

Henderleiter. J., and D. L. Pringle, 1999. Effects of context-based laboratory experiments on attitudes of analytical chemistry students. Journal of Chemical Education 76: 100 - 106.

Hilgard, E. R., and Bower, G. H. (1975). Theories of Learning. Englewood Cliffs, NJ.: Prentice Hall.

Honebein, P. C., Duffy, T. M., and Fishman, B. J. (1993). Constructivism and the design of Learning Environments: Context and authentic activities for learning. In T. M. Duffy, J. Lowyck, D. H. Jonassen, and T. Welsh (Eds.) Designing Environments for Constructive Learning. New York, NY: NATO Scientific Affairs Division.

Jensen, M., Guttschow, G., and Hill, M. (2002). Technophobia and teaching technology-rich freshman science courses. Journal of College Science Teaching 31(6) 360 - 363.

Kant, I., (1974). Logik (translated). Indianapolis: Bobbs-Merrill (original work published 1800).

Kanuka, H., and Anderson, T. (1999). Using Constructivism in Technology-mediated Learning: Constructing order out of the chaos in the literature. Radical Pedagogy 1(2). Retrieved September 16, 2005 from: http://radicalpedagogy.icaap.org/content/issue1_2/02kanuka1_2.html 
Problem-based Learning in an Online Course: A case study

Cheaney \& Ingebritsen

Klemm, W. R. (2002). FORUM for case study learning. Journal of College Science Teaching 32(6), $298-302$.

Margetson, D. (1994). Current educational reform and the significance of problem-based learning. Studies in Higher Education 19(1), 5 - 19.

Maudsley, G. (1999). Do we all mean the same thing by "problem-based learning”? A review of the concepts and a formulation of the ground rules. Academic Medicine 74, 178 - 185.

Michel, M. C., Bischoff, A., and Jakobs, K. H. (2002). Comparison of problem- and lecture-based pharmacology teaching. Trends in Pharmacological Sciences 23, 168 - 170.

Mierson, S. (1998). A problem-based learning course in physiology for undergraduate and graduate basic science students. Advances in Physiology Education 275(supplement) S16 $-\mathrm{S} 27$.

Molenda, M., (1991). A philosophical critique of the claims of “constructivism.” Educational Technology 31(10), $44-48$.

Morgan, A., (1983). Theoretical aspects of project based learning in higher education. British Journal of Educational Technology 14(1) 68 - 78.

Mullins, G., 1994. The evaluation of teaching in a problem-based learning context. In S. E. Chen, R. Cowdroy, A. Kingsland, and M. Ostwald (Eds.), Reflections on Problem Based Learning (p. 105-124). Sydney: Australian Problem Based Learning Network.

Navarra, J. G., Levin, J., and Navarra, J. G. Jr., (1993). An example of the use of meteorological concepts in the problem-based general-education experiences of undergraduates. Bulletin of the American Meteorological Society 74, 439 - 446.

Oliver, R., and Herrington, J. (2000). Using situated learning as a design strategy for Web-based learning. In B. Abbey (Ed.) Instructional and Cognitive Impacts of Web-based Education (p. 178-191). Hershey, PA: Idea Group Publishing.

Patel, V. L., Groen, G. J., and Norman, G. R. (1991). Effects of conventional and problem-based medical curricula on problem solving. Academic Medicine 66, 380 - 389.

Peters, A. S., Greenberger-Rosovsky, R., Crowder, C., Block, S. D., and Moore, G. T. (2000). Long-term outcomes of the New Pathway Program at Harvard Medical School: A randomized controlled trial. Academic Medicine 75, 470-479.

Russell, A. L., Creedy, D., and Davis, J. (1994). The use of contract learning in PBL. In S. E. Chen, R. Cowdroy, A. Kingsland, and M. Ostwald (Eds.) Reflections on Problem Based Learning (p. 57-72). Sydney: Australian Problem Based Learning Network.

Russell, T. L. (2001). The No Significant Difference Phenomenon (5th ed.). Montgomery, AL.: International Distance Education Certification Center. 
Problem-based Learning in an Online Course: A case study

Cheaney \& Ingebritsen

Ryan, G. L., and Quinn, C. N. (1994). Cognitive apprenticeship and problem based learning. In S. E. Chen, R. Cowdroy, A. Kingsland, and M. Ostwald (Eds.) Reflections on Problem Based Learning (p. 15-33). Sydney: Australian Problem Based Learning Network.

Ryle, A. (1975). Frames and Cages: The repertory grid approach to human understanding. London: University of Sussex Press.

Savery, J. R., and Duffy, T. M. (1995). Problem Based Learning: An instructional model and its constructivist framework. Educational Technology 35(5), 31 - 37.

Schmidt, H. G. (1993). Foundations of Problem-based Learning: Some explanatory notes. Medical Education 27, 422 - 432.

Shannon, S., and Brine, J. (1994). Consolidating professional skills and developing the confidence of graduating architects. In S. E. Chen, R. Cowdroy, A. Kingsland, and M. Ostwald (Eds.) Reflections on Problem Based Learning (p. 201-217). Sydney: Australian Problem Based Learning Network.

Shunk, D. H. (2000). Learning Theories: An educational perspective (3rd ed.). Upper Saddle River, NJ.: Prentice-Hall.

Spiro, R. J., Feltovich, P. J., Jacobsen, M. J., and Coulson, R. L. (1991). Cognitive Flexibility, Constructivism, and Hypertext: Random access instruction for advanced knowledge acquisition in ill-structured domains. In T. Duffy and D. Jonassen (Eds.) Constructivism and the Technology of Instruction. Hillsdale, NJ.: Lawrence Erlbaum Associates.

Spiro, R. J., and Jehng, J. C. (1990). Cognitive Flexibility and Hypertext: Theory and technology for the nonlinear and multidimensional traversal of complex subject matter. In D. Nix and R. J. Spiro (Eds.) Cognition, Education, and Multimedia: Exploring Ideas in High Technology. Hillsdale, NJ.: Lawrence Erlbaum Associates.

Steel, R. G. D., and Torrie, J. H. (1960). Principles and Procedures of Statistics with Special Reference to the Biological Sciences. New York, NY.: McGraw-Hill.

Tolnai, S. (1991). Continuing medical education and career choice among graduates of problembased and traditional curricula. Medical Education 25(5), $414-420$.

von Glaserfeld, E. (1989). Cognition, construction of knowledge and teaching. Synthese 80, 121 140.

von Glaserfeld, E., and Smock, C. (1974). Introduction. In C. Smock and E. von Glaserfeld (Eds.) Epistemology and Education: The Implications of Radical Constructivism for Knowledge Acquisition. Mathemagenic Activities Program - Follow Through. Athens, GA.: University of Georgia.

Wankat, P. C. and Oreovicz, F. S. (1991). Teaching Engineering. New York: McGraw-Hill. 
White, H. B. (1996). Dan tries Problem-based Learning: A case study. In L. Richlin (Ed.) To Improve the Academy, Vol. 15 (p. 75-91). Stillwater, OK.: New Forums Press and the Professional and Organizational Network in Higher Education.

Willingham, D. T. (2004). Reframing the Mind. Education Next 4(3), 18 - 24.

Wright, J., Millar, S., Kosciuk, S., Penberthy, D., Williams, P., and Wampold, B. (1998). A novel strategy for assessing the effects of curriculum reform on student competence. Journal of Chemical Education 75, 986 - 992. 